\title{
Perioperative dexketoprofen or lornoxicam administration for pain management after major orthopedic surgery: a randomized, controlled study
}

\section{Majör ortopedik cerrabi sonrası ăgrı tedavisinde deksketoprofen veya lornoksikam kullanımı: Randomize ve kontrollü bir çalışma}

\author{
Nükhet SiVRIKOZ, Kemalettin KOLTKA, Ece GÜRESTi, \\ Mehmet BÜGET, Mert ŞENTÜRK, Süleyman ÖZYALÇIN
}

\begin{abstract}
10
\section{Summary}

Objective: Non-steroidal anti-inflammatory drugs (NSAIDs) are recommended for multimodal postoperative pain management. The purpose of this study was to evaluate the postoperative pain relief and opioid-sparing effects of dexketoprofen and lornoxicam after major orthopedic surgery.

Methods: After obtaining ethical committee approval and informed consent, 120 patients undergoing elective hip or knee replacement under general anesthesia were randomized to receive two intravenous injections of $50 \mathrm{mg}$ dexketoprofen (GD), $8 \mathrm{mg}$ lornoxicam (GL) or saline as placebo (GP) intravenously. Postoperatively, patient-controlled analgesia (PCA) morphine was started as a $0.01 \mathrm{mg} \cdot \mathrm{kg}^{-1}$ bolus dose, with lockout time of 10 minutes without continuous infusion. Pain assessment was made using the Visual Analogue Scale (VAS) at rest or during movement at postoperative 1, 2, 4, 6, 8, 12, and 24 hours.

Results: The three groups were similar in terms of age, gender, American Society of Anesthesiologists (ASA) class, number of patients who underwent hip or knee surgery, weight, height, and operation duration. Patients in GD and GL demonstrated significantly reduced pain scores at rest and active motion compared to GP, with lower scores in the dexketoprofen group. Patients in GD and GL used significantly less morphine in the postoperative period compared to GP. The total morphine consumption of patients in GD was lower than in GL.

Conclusion: Intravenous application of $50 \mathrm{mg}$ dexketoprofen twice a day and $8 \mathrm{mg}$ lornoxicam twice a day improved analgesia and decreased morphine consumption following major orthopedic surgery. When the two active drugs were compared, it was found that dexketoprofen was superior to lornoxicam in terms of analgesic efficacy and opioid consumption.

Key words: Analgesia; dexketoprofen; lornoxicam; postoperative pain; major orthopedic surgery.
\end{abstract}

\section{Özet}

Amaç: Non-steroidal antienflamatuvar ilaçlar (NSAİI) multimodal ameliyat sonrası ağrı tedavisinde kullanılması önerilen ilaçlardir. Bu çalışmanın amacı majör ortopedik cerrabi sonrasında kullanılan deksketoprofen ve lornoksikamın ameliyat sonrası analjezik etkinliğini ve morfin tüketiminde yaptığı azalmayı incelemektir.

Gereç ve Yöntem: Etik kurul izni ve hasta onamı alındiktan sonra genel anestezi altında elektif kalça veya diz total protezi uygulanacak 120 hasta iki doz $50 \mathrm{mg}$ deksketoprofen (GD), iki doz $8 \mathrm{mg}$ lornoksikam (GL) veya plasebo (GP) alacak şekilde randomize edildi. Ameliyat sonrası dönemde, $0.01 \mathrm{mg} \cdot \mathrm{kg}^{-1}$ bolus doz ve kilitli kalma 10 dak olacak şekilde morfin içeren HKA bazal infüzyon olmadan başlandı. Ağrı değerlendirmesi ameliyat sonrası 1, 2, 4, 6, 8, 12 ve 24. saatlerde istirahat ve hareket balinde VAS ile yapıldı. Bulgular: Gruplar arasında yaş, cinsiyet, ASA değeri, kalça ve diz protezi yapılan hasta sayısı, ă̆ırlı, boy ve operasyon süresi açısından fark yoktu. GD ve GL hastalarının istirabat ve aktif hareket halindeki VAS değerleri GP'deki hastalardan anlamlı olarak daba düşüktü. GD'nin istirahat ve aktif hareket balindeki VAS değerleri GL'den daba düşük olarak bulundu. GD ve GL'deki hastalarin ameliyat sonrast morfin tüketimi GP'dekilerden anlamlı olarak daba düşüktü. GD'deki hastalarin toplam morfin tüketimi GL'den daha düşük bulundu.

Sonuç: Elli $\mathrm{mg}$ deksketoprofenin ve $8 \mathrm{mg}$ lornoksikamin intravenöz yoldan günde iki doz uygulanmasinın majör ortopedik cerrabi sonrası plaseboya göre daha iyi analjezi sağladığı ve morfin tüketimini azalttığı bulundu. İki aktif ilaç karşılaştırıldı̆̆ında ise analjezik etkinlik ve morfin tüketimi açısından deksketoprofen lornoksikamdan daha üstün bulundu.

Anahtar sözcükler: Ameliyat sonrası ağrı; analjezi; deksketoprofen; lornoksikam; majör ortopedik cerrahi.

Department of Anesthesiology, Istanbul University Istanbul Faculty of Medicine, Istanbul, Turkey Istanbul Üniversitesi İstanbul Tıp Fakültesi, Anesteziyoloji Anabilim Dalı, İstanbul

Submitted (Başvuru tarihi) 16.01.2012 Accepted after revision (Düzeltme sonrası kabul tarihi) 25.12.2012

Correspondence (IIletişim): Dr. Kemalettin Koltka. İstanbul Üniversitesi İstanbul Tıp Fakültesi, Anesteziyoloji Anabilim Dalı, 34390 Fatih, İstanbul, Turkey. Tel: +90 - 216 - 3457383 e-mail (e-posta): ahmetkoltka@yahoo.com 


\section{Introduction}

Patients undergoing total hip replacement (THR) may experience moderate to severe pain while most if not all of the patients undergoing total knee replacement (TKR) will have severe postoperative pain. Effective pain therapy is an important challenge for the anaesthesiologist since it may reduce pain-related problems and improve postoperative outcome. $^{[1,2]}$ Although opioids are accepted as the mainstay for moderate to severe postoperative pain treatment they are generally combined with other analgesics to decrease both consumptions and opioid related side effects. ${ }^{[3-7]}$

Dexketoprofen trometamol is a water-soluble salt of the $S(+)$-enantiomer of the racemic compound ketoprofen. ${ }^{[7]}$ It has been shown that the anti-inflammatory and analgesic effect of ketoprofen is due entirely to the $S(+)$-enantiomer (dexketoprofen), while the $\mathrm{R}(-)$-enantiomer is devoid of such activity. ${ }^{[7]}$ There is evidence that the $\mathrm{R}(-)$-enantiomer has the ulcerogenic activity and dexketoprofen produces equivalent analgesia to double dose ketoprofen with less risks of harm. ${ }^{[8]}$

Lornoxicam is a member of oxicam group non-steroidal anti-inflammatory drugs (NSAIDs) with an improved gastrointestinal toxicity profile. ${ }^{[9]}$ The relatively short half-life of lornoxicam is an advantage of lornoxicam over other NSAIDs because longer plasma half-lives have previously been linked to a high incidence of adverse events. ${ }^{[10]}$

The aim of this prospective, randomized, and placebo controlled study was to compare the efficacy and safety of intravenous dexketoprofen trometamol $50 \mathrm{mg}$ with that of $8 \mathrm{mg}$ intravenous lornoxicam and placebo after major orthopedic surgery (THR or TKR).

\section{Materials and Methods}

With the approval of local ethics committee and signed informed consent of the patients, 120 American Society of Anesthesiologists (ASA) I-III patients underwent elective unilateral hip or knee replacement surgery were included in the study. Patients with endocrine disorders, severe hepatic and renal diseases, neuropathies, bleeding disorders, preexist- ing gastric ulcers, gastritis, and history of gastrointestinal bleeding, dementia, cooperation disability and sensitivity to dexketoprofen, lornoxicam or morphine were not included. All patients were informed about pain evaluation with visual analogue scale (VAS) and using the patient controlled analgesia (PCA) device during a preoperative visit the day before the surgery.

\section{Anesthetic technique}

All patients had $0.01 \mathrm{mg} / \mathrm{kg}$ intravenous midazolam for premedication. Heart rate (HR), peripheral oxygen saturation $\left(\mathrm{SpO}_{2}\right)$ and non-invasive blood pressures were monitored by Horizon XL during the surgery. During induction $2 \mathrm{mcg} / \mathrm{kg}$ fentanyl, $2-3 \mathrm{mg} /$ $\mathrm{kg}$ propofol were given, and trachea was intubated after vecuronium $0.1 \mathrm{mg} / \mathrm{kg}$. During maintenance of anaesthesia 1-2\% sevoflurane was applied in 40\% $\mathrm{O}_{2}$, and $60 \% \mathrm{~N}_{2} \mathrm{O}$. A hundred and twenty patients were randomly assigned, using sealed numbered and opaque envelopes to one of the three groups of 40 patients. The first injection was administered at the end of the surgery, with the first closing stitch and the second injection was administered 12 hours later. All study drugs were given as $2 \mathrm{ml}$ solutions. In order to maintain double-blind conditions, study drugs were prepared and injected by medical staff that was not involved in pain evaluations.

Group dexketoprofen (GD): Patients $(\mathrm{n}=40)$ had 50 $\mathrm{mg}$ intravenous dexketoprofen trometamol twice a day: first dose was applied at the end of the surgery, with the first closing stitch and the second injection was administered 12 hours later.

Group lornoxicam (GL): Patients $(\mathrm{n}=40)$ had $8 \mathrm{mg}$ intravenous lornoxicam twice a day: first dose was applied at the end of the surgery, with the first closing stitch and the second injection was administered 12 hours later.

Group placebo (GP): Patients ( $\mathrm{n}=40)$ had $2 \mathrm{ml}$ intravenous saline twice a day: first dose was applied at the end of the surgery, with the first closing stitch and the second injection was administered 12 hours later.

\section{Postoperative analgesia}

In the recovery room patients were given $0.05 \mathrm{mg} / \mathrm{kg}$ intravenous morphine as required to stabilize their 
pain and at the same time for postoperative analgesia use of the PCA device was started (IV morphine $0.01 \mathrm{mg} / \mathrm{kg}$ bolus dose and $10 \mathrm{~min}$ lockout time).

\section{Evaluation parameters}

During the postoperative period, the degree of subjects' pain was evaluated with a 0 - to $100 \mathrm{~mm}$ Visual Analog Scale (VAS). Scores were obtained at one, two, four, $6,8,12$, and 24 hours after surgery at rest and during movement. Total morphine consumption via PCA device at the twenty fourth postoperative hours and the number of bolus demands in the first 24 hours postoperatively was recorded by an anesthesiologist who was blinded to the solution administered.

\section{Statistical analysis}

Based on a previous we calculated a group size of 34 patients would be sufficient to detect a difference of $20 \% \mathrm{~cm}$ on the VAS during movement at a threshold of 0.1 with a power of analysis $95 \%$.

Differences among groups for the primary endpoint were tested using an analysis of variance (ANOVA). Secondary endpoints were analyzed using an ANOVA or Kruskall-Wallis, chi-square, or McNemar test as appropriate. Differences in group demographic characteristics were tested by ANOVA or contingency table chi-square test for categorical measures. A level of $\mathrm{p}<0.05$ was considered statistically significant.

\section{Results}

A hundred and twenty patients were enrolled in the study. One patient from the lornoxicam group was excluded due to PCA device failure. One patient in the control group developed fever and was given an antipyretic drug and was excluded. Therefore, a total of 118 patients were included to full-analysis population for efficacy. A comparison of groups with respect to age, sex, body weight and operative characteristics showed no statistically significant difference (Table 1).

\section{VAS scores at rest}

At the early postoperative period the rest VAS scores of all groups were high and decreased in time; the reduction of VAS scores $(\leq 40)$ of GD patients were faster while it was slowest in GP patients.

Patients in GD and GL had significantly lower VAS scores than patients in GP at 1, 2, 4, 8, 12, and 24 $\mathrm{h}$ postoperatively at rest. Also, the VAS values of GL patients were significantly higher than GD patients at 1,2 and $4 \mathrm{~h}$ at rest (Table 2).

\section{VAS scores during movement}

At the early postoperative period VAS scores of all the groups during movement were high and decreased in time; the reduction of VAS scores were faster in GD patients while it was slowest in GP patients (Figure 1).

GD patients had significantly lower VAS values than patients in GL during movement throughout the study period except the 24th h. GD patients had significantly lower VAS values than patients in GP during movement throughout the study period. GL patients had significantly lower VAS values than patients in GP at 2, 4, 6, 8, 12, and 24 h postoperatively during movement (Figure 1).

Table 1. Patient characteristics (Mean \pm SD)

\begin{tabular}{|c|c|c|c|c|c|c|}
\hline & \multicolumn{2}{|c|}{ Group D } & \multicolumn{2}{|c|}{ Group L } & \multicolumn{2}{|c|}{ Group P } \\
\hline & $\mathbf{n}$ & Mean \pm SD & $\mathbf{n}$ & Mean \pm SD & $\mathbf{n}$ & Mean \pm SD \\
\hline Age (years) & & $62.3 \pm 9$ & & $58.7 \pm 9.6$ & & $61.8 \pm 8.4$ \\
\hline Weight (kg) & & $74.9 \pm 10.7$ & & $72.7 \pm 11.9$ & & $72 \pm 11.5$ \\
\hline Operation time (min) & & $100 \pm 18.5$ & & $102.8 \pm 17.3$ & & $98.5 \pm 17.1$ \\
\hline Anesthesia time & & $122.5 \pm 16.7$ & & $126.6 \pm 18.6$ & & $124.6 \pm 15.7$ \\
\hline Sex (Female/Male) & $22 / 16$ & & $20 / 19$ & & $19 / 20$ & \\
\hline THR/TKR & $18 / 20$ & & $17 / 22$ & & $21 / 18$ & \\
\hline
\end{tabular}

THR: Total hip replacement; TKR: Total knee replacement; SD: Standart deviation. 
Table 2. VAS scores at rest (Mean \pm SD)

\begin{tabular}{lccc}
\hline VAS at Rest & GD & GL & GP \\
\hline Postop 1st h VAS & $53 \pm 8^{\& \& \&_{1}^{* * *}}$ & $70 \pm 6^{* * *}$ & $80 \pm 5$ \\
Postop 2nd h VAS & $48 \pm 8^{\& \& \varepsilon_{,}^{* * *}}$ & $67 \pm 6$ & $72 \pm 10$ \\
Postop 4th h VAS & $37 \pm 7^{\& \& \&^{* * *}}$ & $54 \pm 9.5^{* *}$ & $64 \pm 10$ \\
Postop 6th h VAS & $32 \pm 9$ & $39 \pm 10$ & $40 \pm 11$ \\
Postop 8th h VAS & $25 \pm 9^{* *}$ & $22 \pm 9^{* * *}$ & $36 \pm 11$ \\
Postop 12th h VAS & $13 \pm 8^{* * *}$ & $15 \pm 9^{* * *}$ & $31 \pm 13$ \\
Postop 24th h VAS & $10 \pm 6^{* * *}$ & $11 \pm 6^{* * *}$ & $26 \pm 10$ \\
\hline VAS: Visual Analog Scale; Postop: Postoperative; ${ }^{* *}$ p<0.01 when compared with GP; ***: $\mathrm{p}<0.001$ when com- \\
pared with GP; \&\&\&: $p<0.001$ when compared with GL.
\end{tabular}

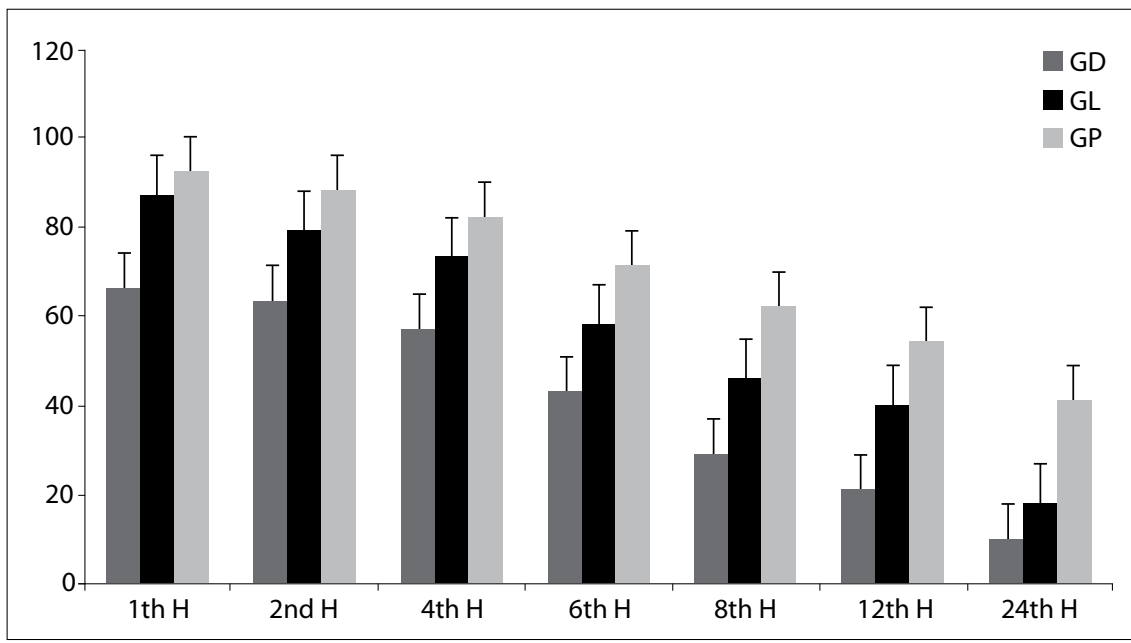

Figure 1.Visual Analog Scale scores during active movement.

\section{Morphine Consumptions of the Groups}

Patients in GD used $11.5 \mathrm{mg}$ (range 7-16.8 mg) morphine while GL patients used $14.6 \mathrm{mg}$ (range 10.6-18 mg) and GP patients used $22.9 \mathrm{mg}$ (range $16.9-32 \mathrm{mg})(\mathrm{p}<0.001$ and GD vs. GP $\mathrm{p}<0.001, \mathrm{GL}$ vs. GP $\mathrm{p}<0.001$ and GD vs. GL $\mathrm{p}<0.01)$.

Patients in GD had a median of 16 boluses (range 12-20) while GL patients had a median of 20 boluses (range 16-24) and GP patients had a median of 34 boluses (range 26-36) $(\mathrm{p}<0.0001$ and GD vs. GL $\mathrm{p}<0.001, \mathrm{GD}$ vs. GP $\mathrm{p}<0.001$ and GL vs. GP $\mathrm{p}<0.001)$.

\section{Discussion}

The most important finding of the present study was that IV dexketoprofen trometamol $50 \mathrm{mg}$ twice a day (first dose at the end of surgery and second dose at 12 th hour postoperatively) provided a better pain relief than IV lornoxicam $8 \mathrm{mg}$ twice a day af- ter major orthopedic surgery (THR or TKR) under general anesthesia.

After surgery $20-40 \%$ of all patients experience moderate pain whilst $50-70 \%$ experience severe pain. ${ }^{[11]}$ In the treatment of postoperative pain opioid drugs are used as first line drugs; but because of serious side-effects they are not used in adequate doses to treat moderate to severe pain. ${ }^{[12]}$ Consumptions and the incidence of side effects opioids are reduced by combination of opioids with NSAIDs. ${ }^{[7]}$

In a study comparing intramuscular dexketoprofen trometamol $50 \mathrm{mg}$ with ketoprofen $100 \mathrm{mg}$ and placebo in major orthopedic surgery patients Hanna et al. found out that the opioid consumptions of both dexketoprofen trometamol and ketoprofen were lower than placebo. ${ }^{[7]}$ The protocol of that study is similar to the present one but there are some important differences; instead of ketoprofen, 
lornoxicam is used as the second NSAID and intravenous route is the route of drug application instead of intramuscular application. In that study Hanna et al. found no difference between dexketoprofen trometamol $50 \mathrm{mg}$ and ketoprofen $100 \mathrm{mg}$ in terms of morphine consumption which is not surprising because $1 \mathrm{mg}$ dexketoprofen trometamol is accepted or found out to be equivalent to $2 \mathrm{mg}$ of ketoprofen in several studies. ${ }^{[15,16]}$

In a study comparing $25 \mathrm{mg}$ dexketoprofen trometamol with placebo in elective hip replacement surgery patients Iohom et al. found out that dexketoprofen trometamol was superior to placebo in terms of opioid consumption. ${ }^{[17]}$

Rosenow et al. compared the analgesic efficacy and tolerability of intravenous PCA lornoxicam analgesia with that of morphine in lumbar disc surgery and concluded that lornoxicam via intravenous PCA provided statistically equivalent pain relief to that of morphine with a lower incidence of adverse events. ${ }^{[18]}$ Korkmaz Dilmen et al. compared the analgesic efficacy of lornoxicam, metamizol, and paracetamol with placebo and concluded that metamizol or paracetamol, but not lornoxicam $(16 \mathrm{mg} /$ day), provided effective analgesia following lumbar disc surgery. ${ }^{[19]}$ The results of this study are different from the present one; but variations in the results could be due to the differences in types of surgery, drug administration routes, and PCA protocols.

In a study done on TKR patients Inan et al. compared the morphine consumptions of $32 \mathrm{mg}$ lornoxicam in $48 \mathrm{~h}$ with placebo and found that lornoxicam administration decreased morphine consumption and morphine related side-effects without changing VAS values. ${ }^{[20]}$ In the present study morphine consumption decreased with lornoxicam administration but VAS values also decreased with lornoxicam administration; variations in the results might be due to the differences in types of surgery (TKR vs. THR/ TKR), and PCA protocols.

When we look at VAS values during motion there are a few studies in the literature and in one of these studies Berti et al. compared oral dexketoprofen, oral ketoprofen, or oral paracetamol and demonstrated that in outpatients receiving arthroscopic knee sur- gery, the use of $75 \mathrm{mg} /$ day dexketoprofen was as effective and safe as $150 \mathrm{mg} /$ day racemic ketoprofen, with a better pain relief during motion compared to $2 \mathrm{~g} /$ day paracetamol. ${ }^{[21]}$ In a study done in total hip replacement surgery patients the addition of dexketoprofen to intravenous tramadol PCA resulted in similar levels of VAS during both at rest and motion with less tramadol requirement. ${ }^{[22]}$

To our knowledge this is the first study comparing dexketoprofen and lornoxicam in acute pain treatment. In the systematic review of dexketoprofen made by Moore and Barden it was stated that in all (12/12) randomized trials that compared dexketoprofen (any dose) with placebo dexketoprofen was superior to placebo and in 29/30 active comparator trials dexketoprofen was at least equivalent in efficacy to its active counterpart. ${ }^{[8]}$ Leman et al. compared $25 \mathrm{mg}$ oral dexketoprofen with $50 \mathrm{mg}$ diclofenac in lower limb surgery and showed an earlier onset of analgesic efficacy and more reductions in mean pain scores with dexketoprofen. ${ }^{[22]}$ There are some limitations of the present study. First of all the VAS values of the patients were evaluated just for 24 $\mathrm{h}$ and no long-term data about pain and analgesic requirements were given. Secondly it is not known that the doses of active drugs used are equipotent or not; but the doses were chosen according to the manufacturers' recommendations. These drugs are not compared with each other in major orthopedic surgery and further studies are needed comparing different doses of these drugs. Also the doses that are used in the present study are not higher than the doses used by other investigators. ${ }^{[7,16,19,20]}$

\section{Conclusion}

The results of this study show that $50 \mathrm{mg}$ dexketoprofen trometamol 12 hourly IV was superior to 8 mg lornoxicam 12 hourly IV in terms of pain relief and opioid utilization for major orthopedic surgery (THR/TKR) under general anaesthesia and also both dexketoprofen trometamol and lornoxicam provided better pain relief and less analgesic requirements than placebo.

\section{Conflict-of-interest issues regarding the author- ship or article: None declared.}

Peer-rewiew: Externally peer-reviewed. 


\section{References}

1. White PF. The changing role of non-opioid analgesic techniques in the management of postoperative pain. Anesth Analg 2005;101(5 Suppl):5-22. CrossRef

2. Andersen $L \varnothing$, Husted $H$, Otte KS, Kristensen BB, Kehlet $H$. High-volume infiltration analgesia in total knee arthroplasty: a randomized, double-blind, placebo-controlled trial. Acta Anaesthesiol Scand 2008;52(10):1331-5. CrossRef

3. Elia $\mathrm{N}$, Lysakowski $\mathrm{C}$, Tramèr MR. Does multimodal analgesia with acetaminophen, nonsteroidal antiinflammatory drugs, or selective cyclooxygenase-2 inhibitors and patient-controlled analgesia morphine offer advantages over morphine alone? Meta-analyses of randomized trials. Anesthesiology 2005;103(6):1296-304. CrossRef

4. Hanna MH, Elliott KM, Stuart-Taylor ME, Roberts DR, Buggy D, Arthurs GJ. Comparative study of analgesic efficacy and morphine-sparing effect of intramuscular dexketoprofen trometamol with ketoprofen or placebo after major orthopaedic surgery. Br J Clin Pharmacol 2003;55(2):126-33. CrossRef

5. Karaman S, Gunusen I, Uyar M, Firat V. The effect of pre-operative lornoxicam and ketoprofen application on the morphine consumption of post-operative patient-controlled analgesia. J Int Med Res 2006;34(2):168-75. CrossRef

6. Yazar MA, Inan N, Ceyhan A, Sut E, Dikmen B. Postoperative analgesic efficacy of intravenous dexketoprofen in lumbar disc surgery. J Neurosurg Anesthesiol 2011;23(3):193-7. CrossRef

7. Mauleón D, Artigas R, García ML, Carganico G. Preclinical and clinical development of dexketoprofen. Drugs 1996;52 Suppl 5:24-46. CrossRef

8. Moore RA, Barden J. Systematic review of dexketoprofen in acute and chronic pain. BMC Clin Pharmacol 2008;8:11. CrossRef

9. Radhofer-Welte S, Rabasseda X. Lornoxicam, a new potent NSAID with an improved tolerability profile. Drugs Today (Barc) 2000;36(1):55-76.

10. Paulus HE. Nonsteroidal anti-inflammatory drugs. In: Kelly WN, editor. Textbook of rheumatology. Philadelphia: W.B. Saunders; 1989. p. 776.

11. Schug SA, Merry AF, Acland RH. Treatment principles for the use of opioids in pain of nonmalignant origin. Drugs 1991;42(2):228-39. CrossRef

12. Nuutinen LS, Laitinen JO, Salomäki TE. A risk-benefit apprais- al of injectable NSAIDs in the management of postoperative pain. Drug Saf 1993;9(5):380-93. CrossRef

13. Tuncer S, Pirbudak L, Balat O, Capar M. Adding ketoprofen to intravenous patient-controlled analgesia with tramadol after major gynecological cancer surgery: a double-blinded, randomized, placebo-controlled clinical trial. Eur J Gynaecol Oncol 2003;24(2):181-4.

14. Kehlet H, Dahl JB. The value of "multimodal" or "balanced analgesia" in postoperative pain treatment. Anesth Analg 1993;77(5):1048-56.

15. Barbanoj MJ, Antonijoan RM, Gich I. Clinical pharmacokinetics of dexketoprofen. Clin Pharmacokinet 2001;40(4):245-62.

16. Zippel H, Wagenitz A. Comparison of the efficacy and safety of intravenously administered dexketoprofen trometamol and ketoprofen in the management of pain after orthopaedic surgery: A multicentre, double-blind, randomised, parallel-group clinical trial. Clin Drug Investig 2006;26(9):517-28.

17. Iohom G, Walsh M, Higgins G, Shorten G. Effect of perioperative administration of dexketoprofen on opioid requirements and inflammatory response following elective hip arthroplasty. Br J Anaesth 2002;88(4):520-6. CrossRef

18. Rosenow DE, Albrechtsen M, Stolke D. A comparison of patient-controlled analgesia with lornoxicam versus morphine in patients undergoing lumbar disk surgery. Anesth Analg 1998;86(5):1045-50. CrossRef

19. Korkmaz Dilmen O, Tunali Y, Cakmakkaya OS, Yentur E, Tutuncu AC, Tureci E, et al. Efficacy of intravenous paracetamol, metamizol and lornoxicam on postoperative pain and morphine consumption after lumbar disc surgery. Eur J Anaesthesiol 2010;27(5):428-32. CrossRef

20. Inan N, Ozcan N, Takmaz SA, Ozcan A, Erdoğan I, Baltaci B. Efficacy of lornoxicam in postoperative analgesia after total knee replacement surgery. Agri 2007;19(2):38-45.

21. Berti M, Albertin A, Casati A, Palmisano S, Municino G, da Gama Malcher $M$, et al. A prospective, randomized comparison of dexketoprofen, ketoprofen or paracetamol for postoperative analgesia after outpatient knee arthroscopy. Minerva Anestesiol 2000;66(7-8):549-54.

22. Leman $P$, Kapadia $Y$, Herington J. Randomised controlled trial of the onset of analgesic efficacy of dexketoprofen and diclofenac in lower limb injury. Emerg Med J 2003;20(6):511-3. 